\title{
Identification of Gas Sand Horizons of the Rashidpur Structure, Surma Basin, Bangladesh, Using 2D Seismic Interpretation
}

\author{
Abu Reza Md. Towfiqul Islam ${ }^{1,2}$ and Md. Ahosan Habib ${ }^{3}$ \\ ${ }^{1}$ Department of Disaster Management, Begum Rokeya University, Rangpur 5400, Bangladesh \\ ${ }^{2}$ School of Atmospheric Sciences, Nanjing University of Information Science and Technology, Nanjing 210044, China \\ ${ }^{3}$ Geological Survey of Bangladesh, 100 Pioneer Road, Dhaka 1000, Bangladesh
}

Correspondence should be addressed to Abu Reza Md. Towfiqul Islam; gm_towfique_06@yahoo.com

Received 24 September 2014; Revised 15 December 2014; Accepted 29 December 2014

Academic Editor: Jean-Pierre Burg

Copyright (C) 2015 A. R. Md. T. Islam and Md. A. Habib. This is an open access article distributed under the Creative Commons Attribution License, which permits unrestricted use, distribution, and reproduction in any medium, provided the original work is properly cited.

\begin{abstract}
A total of 13 seismic sections were used for 2D seismic interpretation in order to assess the subsurface geometry of gas sand horizons and hydrocarbon prospect of the Rashidpur structure, Surma Basin, Bangladesh. Out of five reflectors, two selected reflectors were mapped for the study. The top of the Upper Gas Sand (R3) reflector was elongated in N-S with the axis swinging slightly to the east on the northern plunge. North-South trending thrust fault was identified in the eastern part which is parallel to the axial line of the structure. The reflection patterns of the gas sand horizons were parallel to each other and similar in nature. The reflection coefficients were positive at the base and negative at the top of the each gas sand horizons. Velocity dropped from $2562 \mathrm{~m} / \mathrm{s}$ to $2177 \mathrm{~m} / \mathrm{s}$ in the Upper Gas Sand (R3) and $4320 \mathrm{~m} / \mathrm{s}$ to $3413 \mathrm{~m} / \mathrm{s}$ in the Lower Gas Sand (R5) reflector. Bright spot and amplitude anomalies were identified on the top of the both gas sand horizons. The result depicts that the shape of the gas sand horizons is asymmetric anticline. The structure is compressed and elongated NNW-SSE trending anticline. The study reveals hydrocarbon potentiality of the structure.
\end{abstract}

\section{Introduction}

Seismic structural study examines the nature and geometry of the subsurface geology [1]. Seismic study is a common practice to interpret subsurface structure and potentialities of hydrocarbon exploration [2,3]. Some authors have made valuable contributions in different hydrocarbonbearing structure of Surma Basin, Bangladesh, in different time by seismic analysis [4-8]. Few works have also done by hydrocarbon aspects of Bengal Basin, Bangladesh [9-12]. The Rashidpur structure was discovered by the Pakistan Shell Oil Company (PSOC) in 1960. Hossain [13] carried out the study on the application of common depth point shooting of the Rashidpur structure, Surma Basin, Bangladesh. The earlier study was focused on the geophysical interpretation of the Rashidpur structure [14]. The present study emphasized on gas sand horizons to interpret detailed subsurface geometry and to delineate the minor fault of the structure. Different companies carried out seismic study of the structure due to their own commercial purposes. In the study, attempts have been made to incorporate with seismic structural interpretation and hydrocarbon prospects of the Rashidpur structure. The main objective of the study was to map in detail the gas sand horizons and hydrocarbon potentialities of the Rashidpur structure. The Rashidpur structure is situated in the south central part of the Surma Basin under Bahubal Upazila of Habiganj District, Bangladesh (Figure 1).

\section{Geology of the Structure}

Bengal Basin is a prolific hydrocarbon-bearing basin in Southeast Asia. Actually, Surma Basin is a subbasin of Bengal Basin of Bangladesh. The Surma Basin is the northeastern continuation of the Bengal Foredeep and an area of later tectonics than Bengal Basin itself [15]. The Surma Basin is the most important in terms of sediment thickness probably exceeds $20 \mathrm{~km}$ and economic deposits [16]. The Surma 
(m)

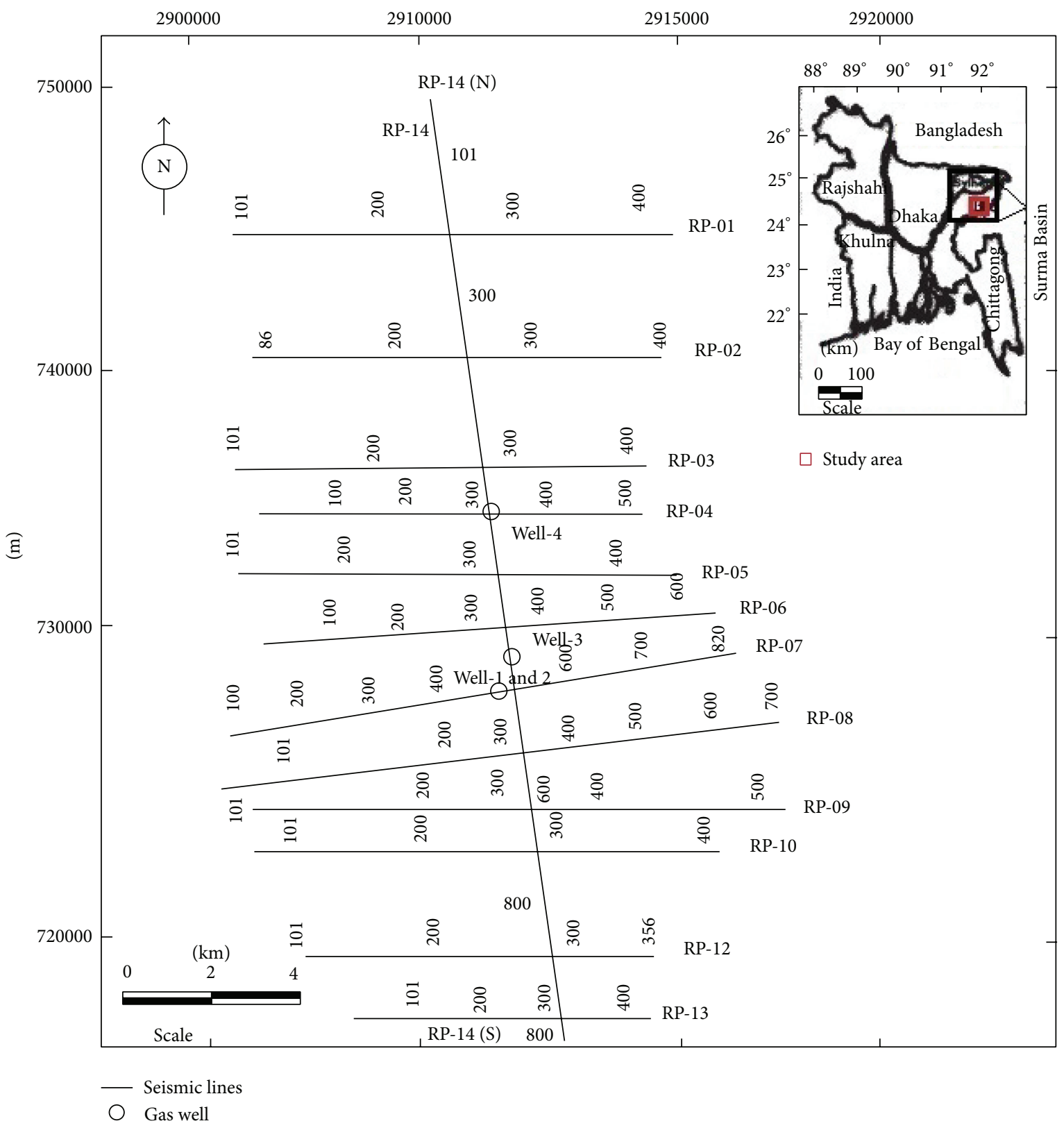

FIGURE 1: Location of the study and shot point map showing the orientation of 13 2D seismic lines (after modification from [14]).

Basin might have been formed at the late orogenic stage due to subsidence along the Dauki Fault system and Pliopleistocene uplift of the Shillong Massif [17]. The tectonics of the basin are considered to be Neogene to Recent with severe period of crustal disturbance. The Rashidpur structure is situated in the southern part of the Surma Basin [14]. As an asymmetrical anticline, the eastern flanks of the structure are steeper $\left(20^{\circ}-25^{\circ}\right)$ than the western flanks [18]. N-S trending Rashidpur structure is at the surface, a narrow anticline about $40.25 \mathrm{~km}$ long and $4.83 \mathrm{~km}$ broad [17]. The Lower to Middle Miocene Surma Group was consisting of the underlying Bhuban Formation and the overlying Boka Bil Formation were deposited during repeated transgression and regression phases of marine environment [19]. Table 1 represents the stratigraphic succession with spatial position in the reflecting horizons on the seismic section of the Rashidpur structure.

\section{Materials and Method}

Seismic data of the study were obtained from the Bangladesh Petroleum Exploration and Production Company Ltd. (BAPEX), a subsidiary company of Bangladesh Oil, Gas and Mineral Corporation (Petrobangla). A total of 13 2D seismic lines of 24-fold coverage were employed for the study (Figure 1). Of these lines, one was strike line and the rest were dip lines. Two reflectors were selected, out of five reflecting 
TABLE 1: Summarized stratigraphic succession with spatial reflectors position in the Rashidpur structure (after BOGMC [4]).

\begin{tabular}{|c|c|c|c|c|c|}
\hline Age & Group & Formation & Lithologic description & $\begin{array}{c}\text { Thickness } \\
\text { approximate }(\mathrm{m})\end{array}$ & Reflectors \\
\hline \multirow[t]{2}{*}{ Plio-Pleistocene } & Dupi Tila & Dupi Tila & $\begin{array}{l}\text { Mainly consists of unconsolidated } \\
\text { sandstones, gray in color, medium to } \\
\text { fine-grained with few soft and soapy } \\
\text { sticky, gray clay, and intercalation of } \\
\text { silt }\end{array}$ & 314 & $\mathrm{R} 1$ \\
\hline & Tipam & $\begin{array}{l}\text { Tipam } \\
\text { Sandstone }\end{array}$ & $\begin{array}{l}\text { Consists of gray, brown to pale gray } \\
\text { coarse-grained sandstones with } \\
\text { intercalation of shale }\end{array}$ & 1030 & $\mathrm{R} 2$ \\
\hline \multirow{4}{*}{$\begin{array}{l}\text { Early to middle } \\
\text { Miocene }\end{array}$} & \multirow{4}{*}{ Surma } & $\begin{array}{l}\text { Upper } \\
\text { Marine Shale }\end{array}$ & Claystone or dark gray shale & $187(?)$ & \multirow{2}{*}{ R3 (UGS) } \\
\hline & & $\begin{array}{l}\text { Boka Bil } \\
\text { Formation }\end{array}$ & $\begin{array}{l}\text { Sandstone, siltstone with alteration of } \\
\text { shale }\end{array}$ & 1100 & \\
\hline & & \multirow[b]{2}{*}{$\begin{array}{l}\text { Bhuban } \\
\text { Formation }\end{array}$} & $\begin{array}{l}\text { Composed mainly of sandstones, silty } \\
\text { sandstones, and shales. The upper part }\end{array}$ & \multirow[b]{2}{*}{$470+$} & $\mathrm{R} 4$ \\
\hline & & & $\begin{array}{l}\text { of this formation consists essentially of } \\
\text { sandstone, light gray, moderately } \\
\text { consolidated very fine-grained with } \\
\text { calcareous cement }\end{array}$ & & R5 (LGS) \\
\hline
\end{tabular}

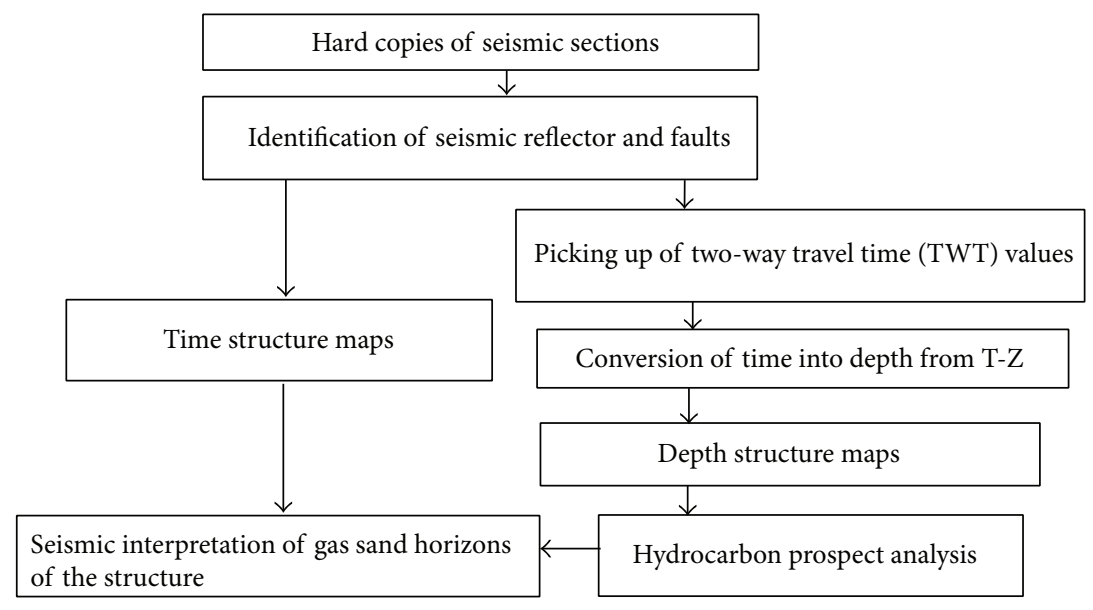

FIgURE 2: Flow chart for the seismic interpretation of gas sand horizons of the Rashidpur structure.

horizons and reflection times were picked up based on tracking the amplitude contrast boundary to prepare time structure maps. The T-Z curve was used for conversion to time (TWT) into depth to prepare depth structure maps. Computation of seismic structural time and depth maps were carried out by Surfer (version 8.0) software. Hydrocarbon prospects were analyzed with the help of amplitude anomaly, reflection coefficient (RC), and velocity analysis of the structure. The reflection coefficients were used to examine positive and negative responses. Any displacement of reflecting horizons due to fault was taken into consideration while picking the horizons and was plotted on the shot point map. After picking up these horizons, the two-way travel time (TWT) for respective reflecting horizons were posted in the shot point map considering certain interval of shot points (SP) and common depth point (CDP). The basic principle of seismic structural interpretation was described by $[20,21]$. The entire processes are summarized in the flow chart shown in Figure 2.

\section{Results and Discussion}

Time (TWT) and depth structural maps were prepared on top of the two selected reflecting horizons. Depths were converted into seismic sections which are convenient for structural interpretation rather than time sections and velocity sections.

4.1. Seismic Structural Analysis. On the basis of reflection continuity, amplitude anomalies, velocity changes, polarity changes, and frequency of the seismic sections, correlation with the wells of the Rashidpur structure were identified five reflectors. Out of five reflectors, two selected gas sand reflectors were selected and correlated with the well information, 
that is, top of the Upper Gas Sand (R3) and top of the Lower Gas Sand (R5) reflectors. Data quality of the seismic lines RP01, RP-02, and RP-06 in the crestal part are fair to good but at about the middle part of the structure in the line RP-04 is very good quality whereas the crestal part of the structure starts to low quality and continue in the lines RP-06 to RP09 data are very poor quality. Again, in the lines RP-10 to RP-13 data started to improve the quality. Figure 3 reveals that geologic interpretation of seismic sequences in terms of TWT (ms) along the seismic section of the lines RP-01, RP07, and RP-13 in the Rashidpur structure. Reflectors are more or less continuous, close-spaced, and parallel in character. The strike line RP-14 and the dip line RP-07 pass through the wells RP \#2, 3, and 4, respectively (Figure 1). The line $\mathrm{RP}-07$ is almost perpendicular to the fault which is located to the eastern flank of the structure (Figure 3). The seismic section of the lines RP-02, RP-04, and RP-07 passes across the structure and line RP-14 along the axis indicate quite a number of reflection anomalies. The dip line RP-04 was identified in the mid part of the structure along W-E direction in the well RP \#4. The line RP-04 on the seismic section at SP 340 represent the boundary between R5 and R4 reflecting horizons at TWT $1900 \mathrm{~ms}$ and between R4 and R3 at TWT $1800 \mathrm{~ms}$ and between R3 and R2 were identified at TWT $1600 \mathrm{~ms}$ and between R2 and R1 at TWT $1200 \mathrm{~ms}$, respectively (Figure 4). The strike line RP-14 was oriented almost along NNW-SSE direction on the real seismic section. It intersects all dip line of the Rashidpur structure and data quality of the strike line RP-14 over the crest is fair to poor (Figure 5).

4.1.1. Upper Gas Sand (R3) Reflector. The Upper Gas Sand (R3) reflector is located at $1200 \mathrm{~ms}$ (TWT). This reflector lies between the time range of $1300 \mathrm{~ms}$ and $2400 \mathrm{~ms}$ TWT which is correlated to the top of the Upper Gas Sand (R3) within the Boka Bil Formation of Early Miocene age. It is identified just above the Bhuban Formation and below the Upper Marine Shale Formation (Table 1). The structure is closed to a depth of $1400 \mathrm{~m}$ which is about $1250 \mathrm{~ms}$ TWT (Figures 6(a), 6(b), 7(a), and 7(b)). Thrust fault is identified on this seismic horizon (Figure 3(b)). Time contour map of the Upper Gas Sand (R3) reflector lies just below the Upper Marine Shale (R2) reflector. This is also observed from the geological cross-section of the time contour map (Figure 3). The structure at the top of the gas sand reflector (R3) is elongated N-S with the axis swinging slightly to the east on the northern plunge and is about $450 \mathrm{~ms}$ below the Upper Marine Shale (R2) reflector. The eastern flank is thrust faulted that extends from the line RP-02 in the north to the line RP12 in the south. This reflector has identified at $1210 \mathrm{~ms}$ TWT in the western flank and the same reflector has identified at $1660 \mathrm{~ms}$ TWT at the eastern flank on the line RP-07. Fault displacement is about $450 \mathrm{~ms}$ TWT (Figure 3(b) and Table 2). Fairly well-developed reflection events have identified and correlated within the fault zone in the lines RP-02, RP-04, and RP-05. However, the depth and time values gradually increase almost uniformly in all directions from the crestal part of gas horizons of the structure.

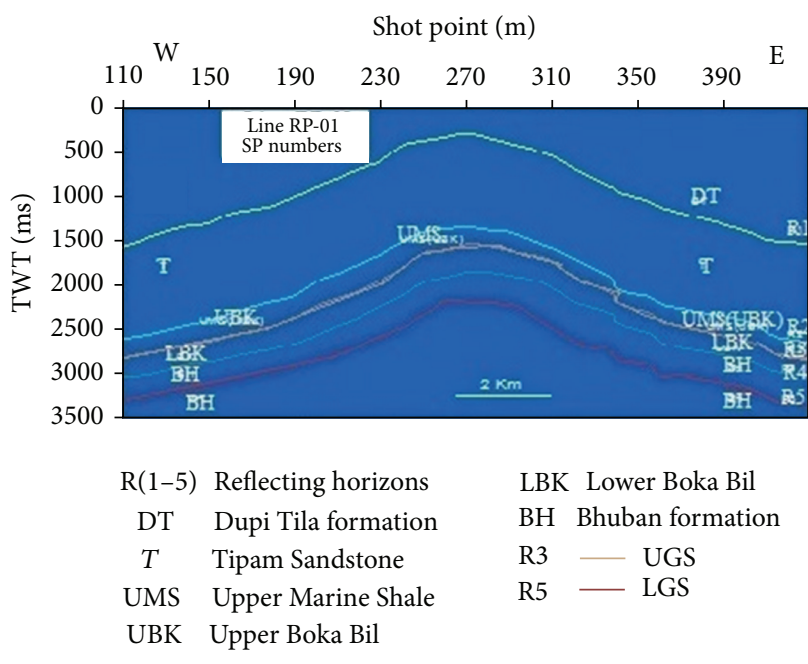

(a)

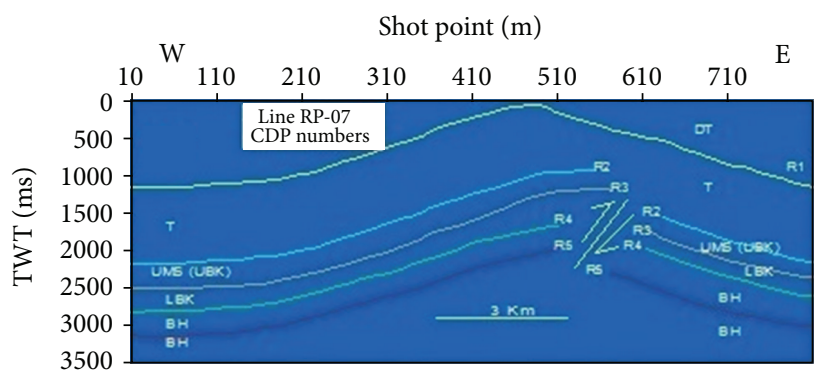

$$
\begin{array}{cl}
\text { R(1-5) } & \text { Reflecting horizons } \\
\text { DT } & \text { Dupi Tila formation } \\
T & \text { Tipam Sandstone } \\
\text { UMS } & \text { Upper Marine Shale } \\
\text { UBK } & \text { Upper Boka Bil }
\end{array}
$$

(b)

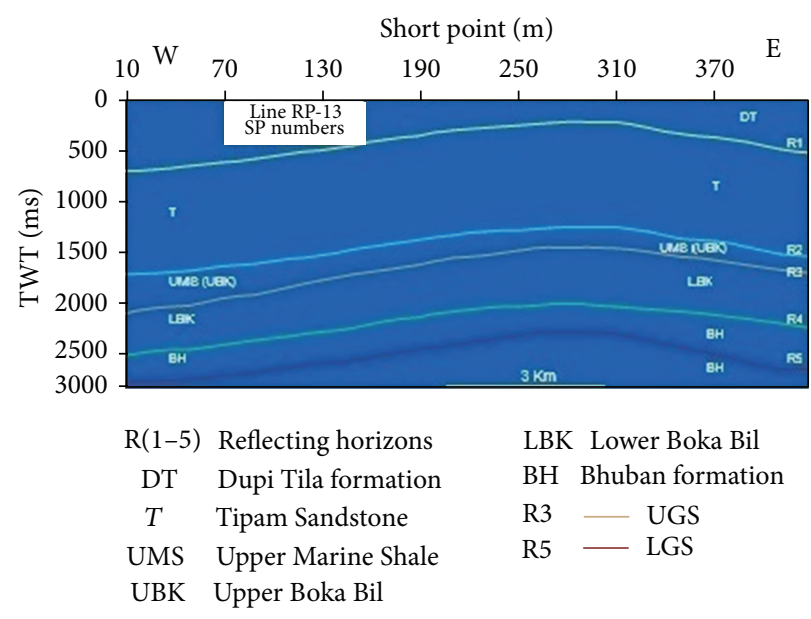

(c)

FIGURE 3: Geologic interpretation of seismic sequences along the seismic sections in the structure, (a) Seismic line RP-01, (b) Seismic line RP-07, and (c) Seismic line RP-13.

4.1.2. Lower Gas Sand (R5) Reflector. The Lower Gas Sand (R5) reflector is located at $1900 \mathrm{~ms}$ (TWT) at the crest on the seismic sections. This deepest reflector lies between 


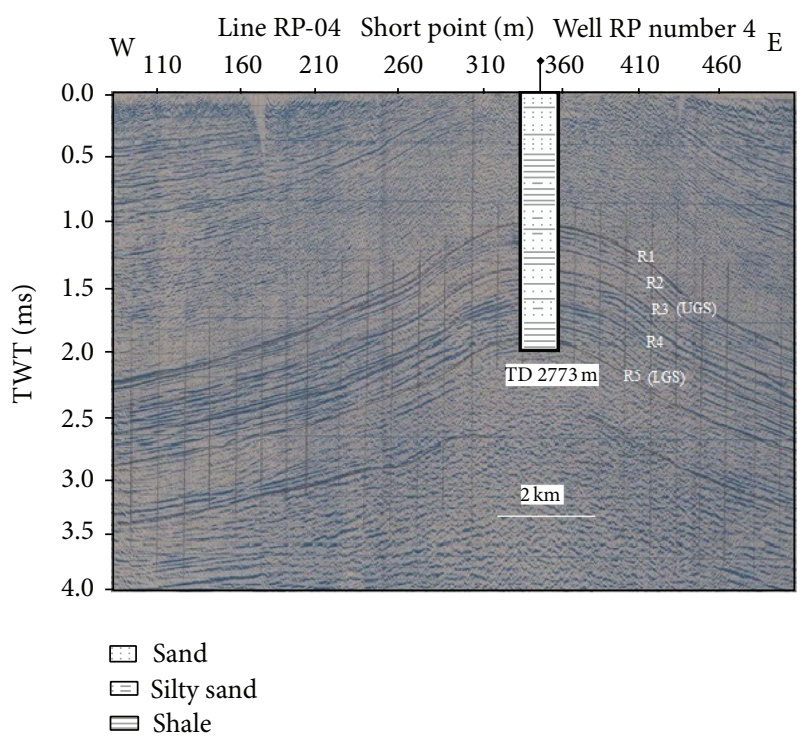

FIGURE 4: Geologic correlation between seismic sections at line RP04 in the well RP \#4 of Rashidpur structure.

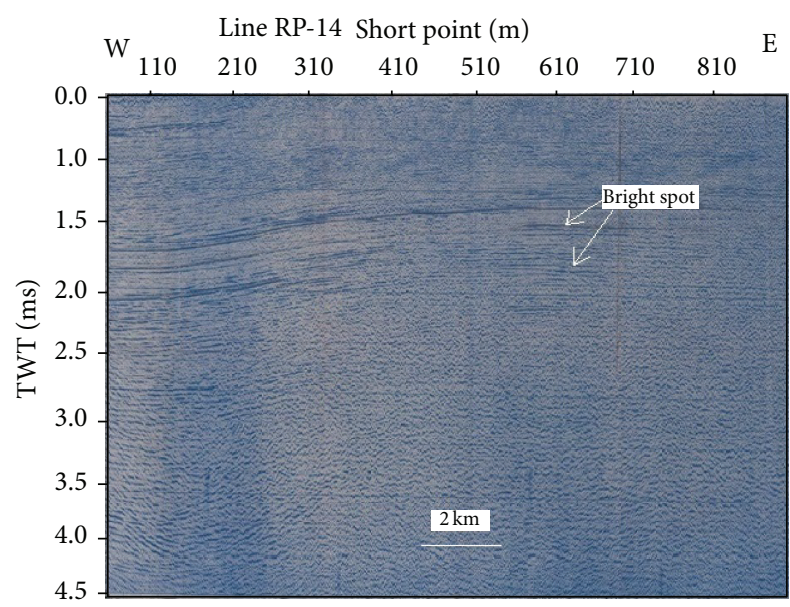

FIGURE 5: Seismic section along the line RP-14 showing bright spot in the structure.

the time range of $1900 \mathrm{~ms}$ and $3000 \mathrm{~ms}$ TWT which is correlated to the top of the Lower Gas Sand (LGS) within the Bhuban Formation of Mid-Lower Miocene age (Table 1). The structure is closed to a $1900 \mathrm{~ms}$ TWT which is about the depth of $2400 \mathrm{~m}$ (Figures 8(a), 8(b), 9(a), and 9(b)). The maximum magnitude of fault is approximately $310 \mathrm{~ms}$ which is identified on the seismic section RP-07 (Figure 3(b) and Table 2). The structure at the top of the Lower Gas Sand (R5) reflector is elongated N-S with the axis swinging slightly to the east on the northern plunge and is about $700 \mathrm{~ms}$ below the Upper Gas Sand reflector (R3). Fairly well developed reflection events have been identified within the fault zone in the lines RP-02 and RP-07 (Figure 11). It lies about $150 \mathrm{~ms}$ below the reflector (R4). The Lower Gas Sand (R5) reflector is not as strong as Upper Marine Shale (R2) reflector as for the Lower Gas Sand (R5) reflector, considerable problem was experienced
TABLE 2: Show identified fault displacement magnitude of gas sand horizons in the structure.

\begin{tabular}{lcc}
\hline \multirow{2}{*}{ Gas sand horizons/reflectors } & \multicolumn{2}{c}{ Fault displacement } \\
& TWT (ms) & Depth (m) \\
\hline UGS (R3) & 450 & 600 \\
LGS (R5) & 310 & 430 \\
\hline
\end{tabular}

in correlating the gas sand horizons. This reflector is of very poor quality in the crestal part of the structure. Presence of numerous faults creates the problems for gas sand horizons. However, the central long zone of these maps has the low depth as well as low time value indicate the crestal part of the horizon of the structure. The structure of the top of the Lower Gas Sand (R5) reflector is about similar in nature to that of the top of the Upper Gas Sand (R3) reflector. Moreover, the major fault is of narrower width but there are numerous other small faults running N-S trend on the eastern flank of the structure.

4.2. Hydrocarbon Prospect Analysis. The presence of gas in a reservoir often produces a detectable suite of response in the seismic sections from the commercial point of view. In the previous work, it is not clearly described the number of seismic parameters which is used to identify the gas sand horizons so far. In the present research, attention has been drawn to consider all the geologic and geophysical evidences concerning hydrocarbon prospects of gas sand horizons in the Rashidpur structure.

4.2.1. Velocity Analysis. The Rashidpur structure shows an almost continuous change in velocity with depth because of its thin layering. The Upper Gas Sand (R3) reflector has the average velocity of $3408 \mathrm{~m} / \mathrm{s}$, which is $45 \%$ greater than that of the earlier of the reflector (R2) and the velocity of Lower Gas Sand (R5) reflector has an average velocity of $4320 \mathrm{~m} / \mathrm{s}$, which is $26.8 \%$ higher than that of the Upper Gas Sand (R5) reflector (Table 3). The lithological change increases in compaction and decreases in porosity with depth are the main reasons behind the velocity fluctuations which increase with depth of the structure. Velocity gradually increases with depth except two gas sand horizons where velocity suddenly dropped. Composite well log responses confirm that the velocity dropped and shown hydrocarbon prospect in the two gas sand horizons of the Rashidpur structure (Figure 10). Islam et al. [15] also found similar result in the well RP \#04 of the Surma Basin. The depth range of $1380 \mathrm{~m}$ to $1462 \mathrm{~m}$ having thickness of $82 \mathrm{~m}$, velocity dropped from $2562 \mathrm{~m} / \mathrm{s}$ to $2177 \mathrm{~m} / \mathrm{s}$, indicates the Upper Gas Sand (R3) reflector. This is because this zone has the higher amount of porosity and gaseous hydrocarbon fills the pore space as a result velocity decreases. Lower Gas Sand (R5) shows different velocities; there is no gradual increase or decrease pattern of velocity change in this part. The depth range of $2706 \mathrm{~m}$ to $2761 \mathrm{~m}$ having thickness of $55 \mathrm{~m}$, velocity dropped from $4320 \mathrm{~m} / \mathrm{s}$ to $3413 \mathrm{~m} / \mathrm{s}$, indicates Lower Gas Sand (R5) reflector (Table 4). These two gas sand horizons have average ranges of porosity from $18 \%$ to $27 \%$ [22]. This porosity is filled with gaseous hydrocarbon [23]. 


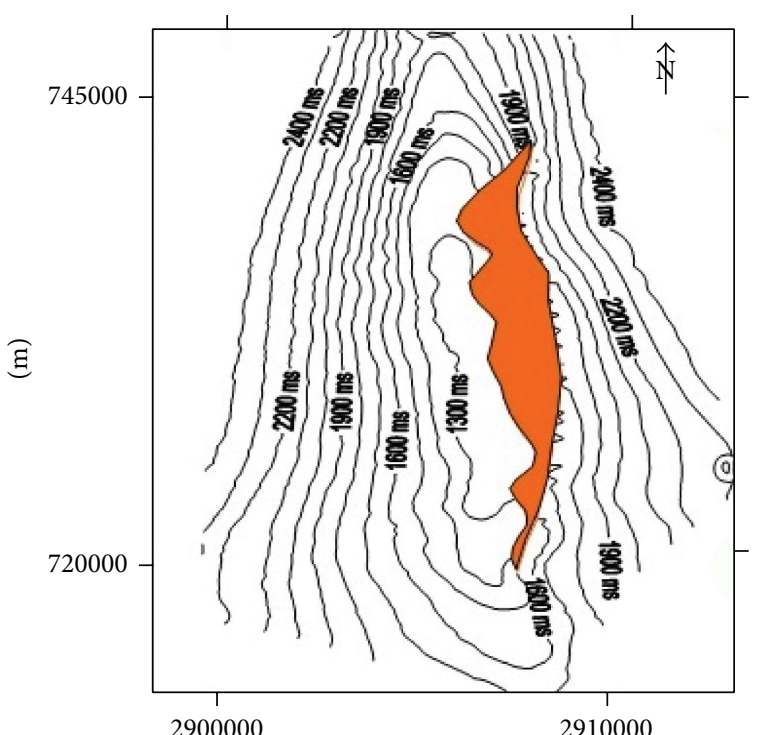

(m)

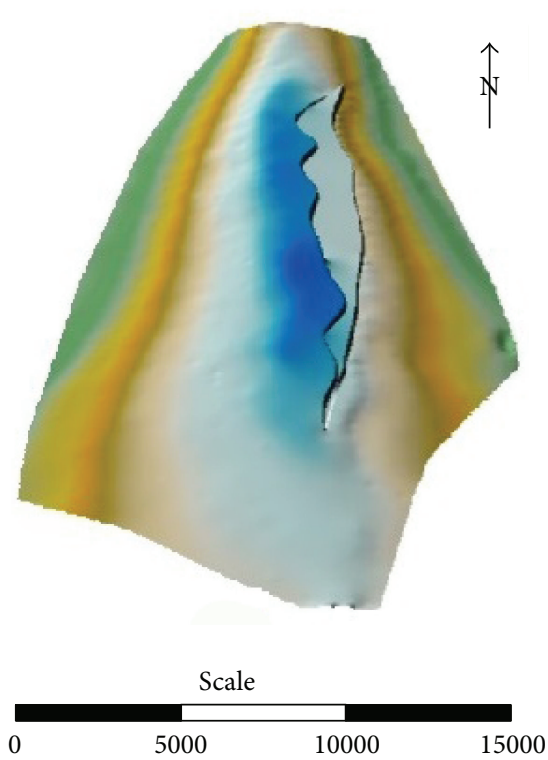

(m)

(a)

(b)

Figure 6: (a) Time structure map on the top of the Upper Gas Sand (R3), Contour interval 100 ms. (b) Subsurface relief map on the top of the Upper Gas Sand (R3).

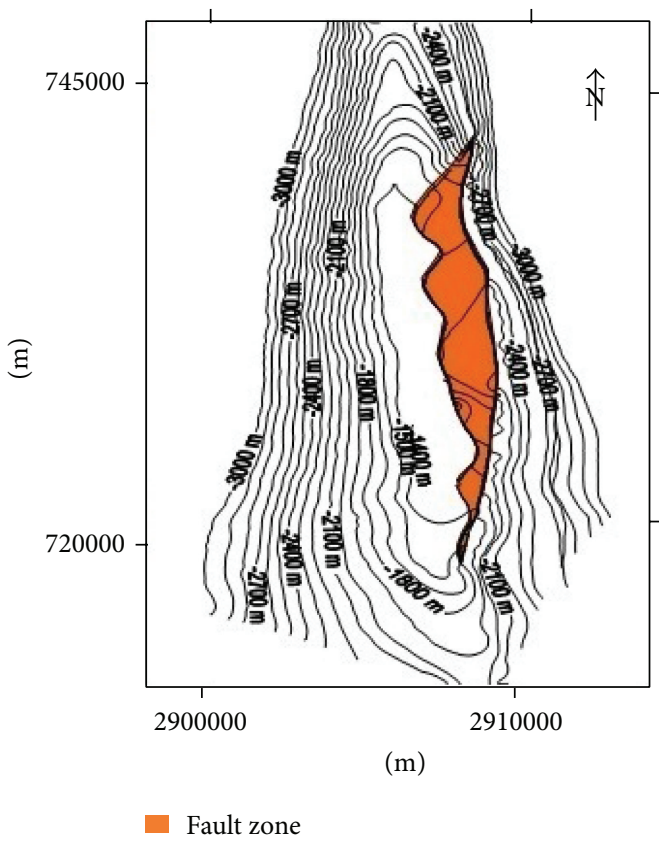

(a)

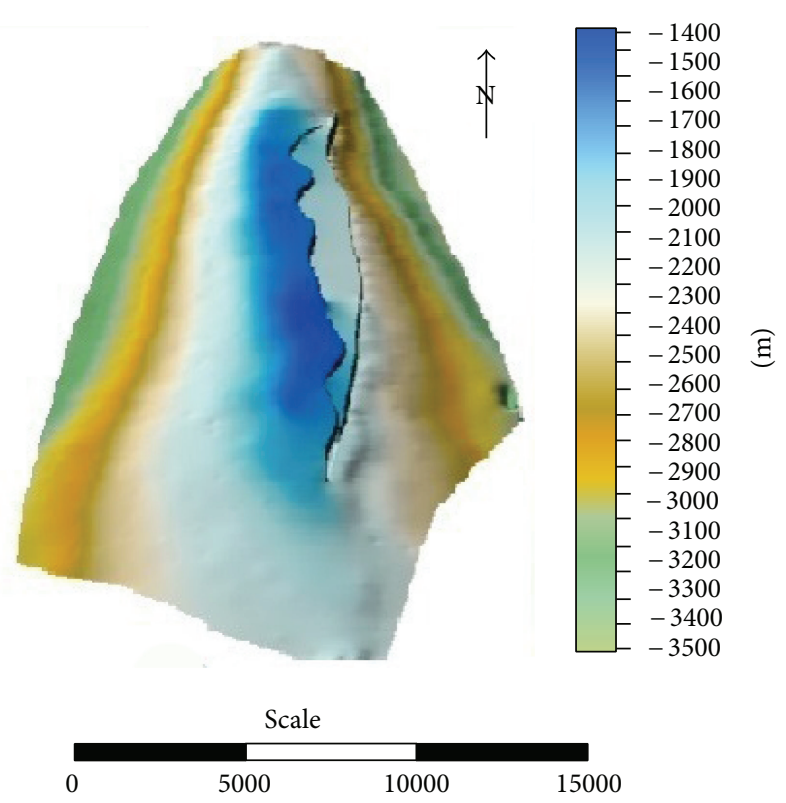

(m)

(b)

Figure 7: (a) Depth structure map on the top of the Upper Gas Sand (R3), Contour interval $100 \mathrm{~m}$. (b) Subsurface relief map on the top of the Upper Gas Sand (R3).

4.2.2. Reflection Coefficient (RC) and Amplitude Response Analysis. The reflection coefficient and the reflection amplitude depend on the contrast in acoustic impedance across the reflecting interface which changes between the cap rock and gas bearing reservoir rock affecting the amplitude and polarity of the top reservoir reflection. The reflection coefficients are positive at the base and negative at the top of the Upper Gas Sand (R3) reflector. Reflection coefficient 


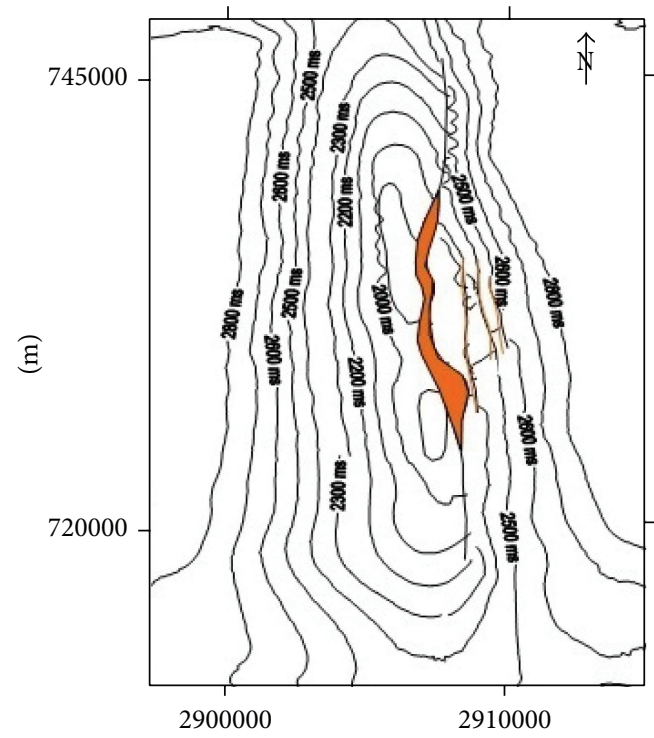

(m)
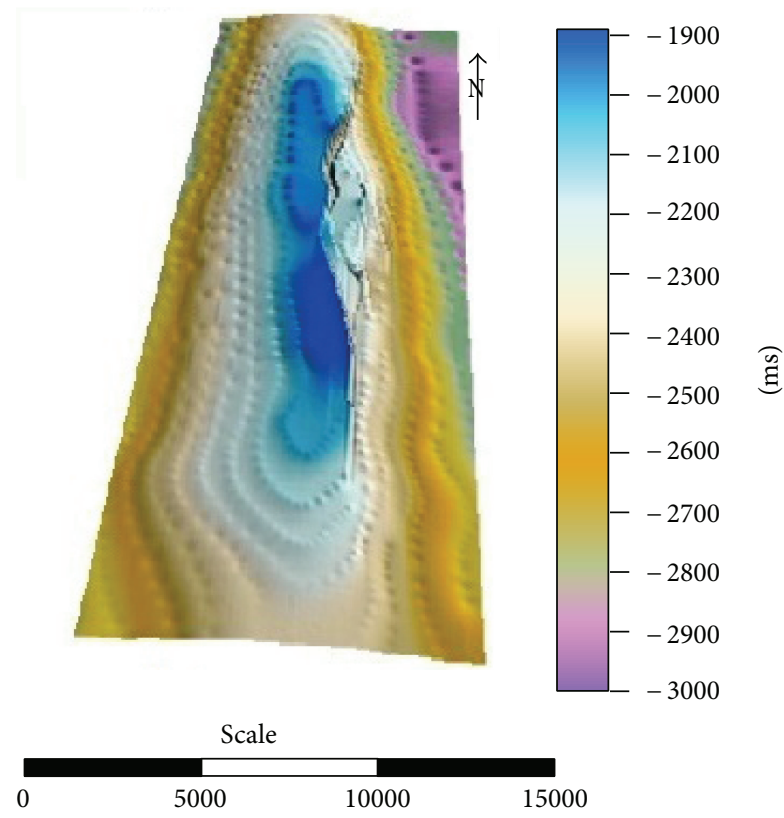

(m)

(a)

(b)

Figure 8: (a) Time structure map on the top of the Lower Gas Sand (R5), Contour interval $100 \mathrm{~m}$. (b) Subsurface relief map on the top of the Lower Gas Sand (R5).

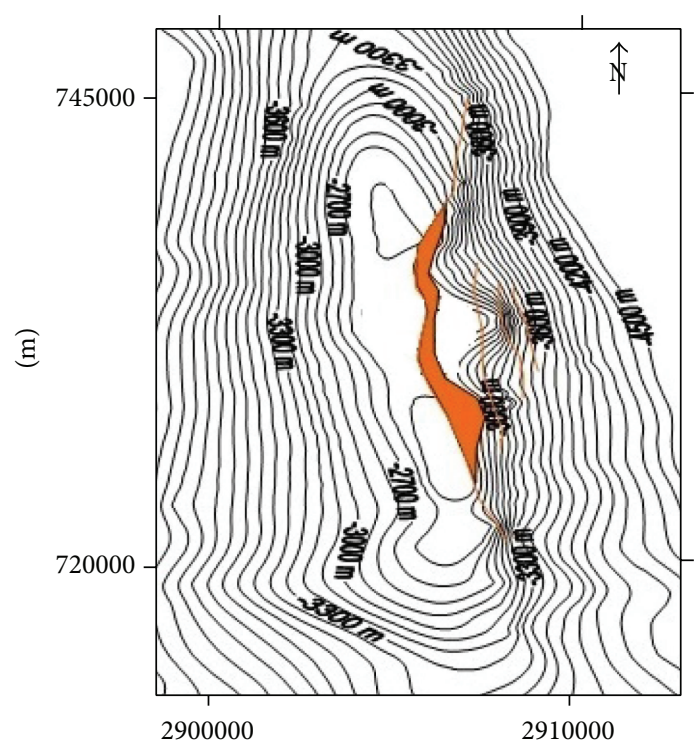

(m)

Fault zone

_ Fault line

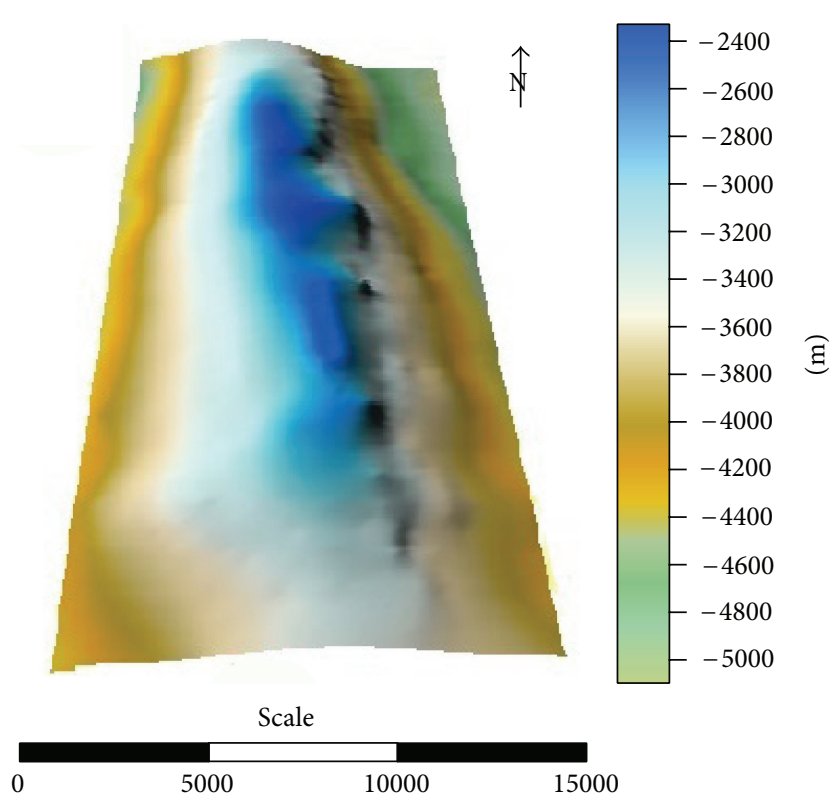

(m)

(a)

(b)

Figure 9: (a) Depth structure map on the top of the Lower Gas Sand (R5), Contour interval 100 ms. (b) Subsurface relief map on the top of the Lower Gas Sand (R5). 


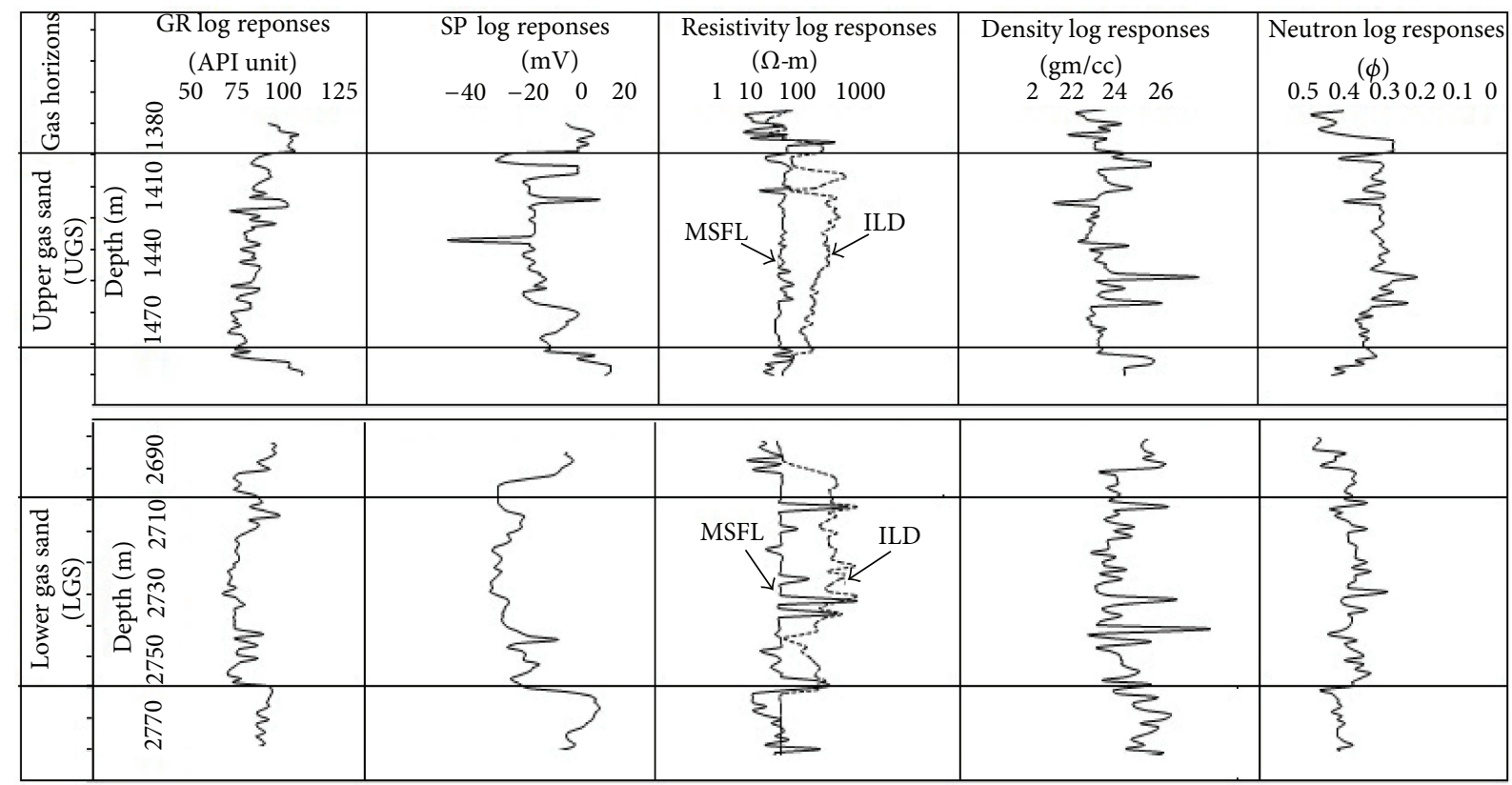

FIGURE 10: Composite well log responses in the gas sand horizons of the well RP \#4 (after Islam et al. [15]).

TABLE 3: Represent average velocity changes with depth of gas sand horizons in the Rashidpur structure.

\begin{tabular}{lccccc}
\hline $\begin{array}{l}\text { Gas sand } \\
\text { horizons/reflectors }\end{array}$ & Depth (m) & Thickness $(\mathrm{m})$ & $\begin{array}{c}\text { Ave. Velocity } \\
(\mathrm{m} / \mathrm{s})\end{array}$ & TWT (sec) & Remarks \\
\hline UGS (R3) & $1380-1462$ & 82 & 3408 & $1.042-1.450$ & $\begin{array}{l}\text { Max. velocity 4012 m/s } \\
\text { Min. velocity 2178 m/s }\end{array}$ \\
\hline LGS (R5) & $2706-2761$ & 55 & 4320 & $1.450-2.918$ & $\begin{array}{l}\text { Max. velocity 5542 m/s } \\
\text { Min. velocity 3387 m/s }\end{array}$ \\
\hline
\end{tabular}

TABLE 4: Show subsurface seismic interfaces of gas sand horizons in the Rashidpur structure.

\begin{tabular}{|c|c|c|c|c|c|c|}
\hline Depth range $(\mathrm{m})$ & $\begin{array}{c}\text { Thickness } \\
(\mathrm{m})\end{array}$ & $\begin{array}{l}\text { Velocity } \\
(\mathrm{m} / \mathrm{sec})\end{array}$ & $\begin{array}{l}\text { Density } \\
\left(\mathrm{kg} / \mathrm{m}^{3}\right)\end{array}$ & $\mathrm{RC}$ & $\mathrm{TC}$ & Reflectors \\
\hline $1332-1380$ & 48 & 2562 & 2206 & -0.057 & 1.057 & \multirow{2}{*}{ R3 (UGS) } \\
\hline 1380-1462 & 82 & 2177 & 2156 & 0.127 & 0.873 & \\
\hline $2630-2706$ & 76 & 4320 & 2414 & -0.085 & 1.085 & \multirow{2}{*}{ R5 (LGS) } \\
\hline $2706-2761$ & 55 & 3413 & 2332 & 0.094 & 0.906 & \\
\hline
\end{tabular}

of the Upper Gas Sand (R3) is 0.127 at the base and -0.057 at the top in depth range from $1380 \mathrm{~m}$ to $1462 \mathrm{~m}$. Reflection coefficient of Lower Gas Sand (R5) reflector is 0.094 at the base and -0.085 at the top in the depth range from $2706 \mathrm{~m}$ to $2761 \mathrm{~m}$ (Table 4 ). The result infers that gas sand horizons are mainly fair to weak type in the structure. The results of RC and TC values are similar to the event amplitudes for the Rashidpur structure [13]. Seismic amplitude anomaly is important to interpret such anomalies with care and to take into account other possible hydrocarbon indicators such as phase change of reflection and pull-down of events beneath the prospective zone, as well as judging the geological feasibility of the anomaly being associated with a gas pool. The amplitude anomaly has identified in the seismic section on the line RP-02 between SP 190 and 230 at TWT $1720 \mathrm{~ms}$ indicates the presence of hydrocarbon (Figure 11(a)). Low acoustic impedance in gas bearing sand as well as higher reflection coefficients indicates the presence of gas in the reservoir [24]. Top of the UGS and the LGS reflectors give higher reflection amplitude accompanied by corresponding polarity changes. A polarity reversal of the top of the gas sand horizon is a common feature of bright spot (Figure 5). A flat spot is visible in the southern part of the structure on the lines RP-07 at the intersection with line RP-14 at CDP 661 (Figure 11(b)). Flat spots are perhaps the best indications for gas and mark the gas/water contact. Flat spots always have positive RC appearing as a trough on the seismic sections with normal polarity or a peak on reverse polarity sections. Reflection amplitude analysis is important for hydrocarbon prospect analysis, which is directly controlled by the velocity 

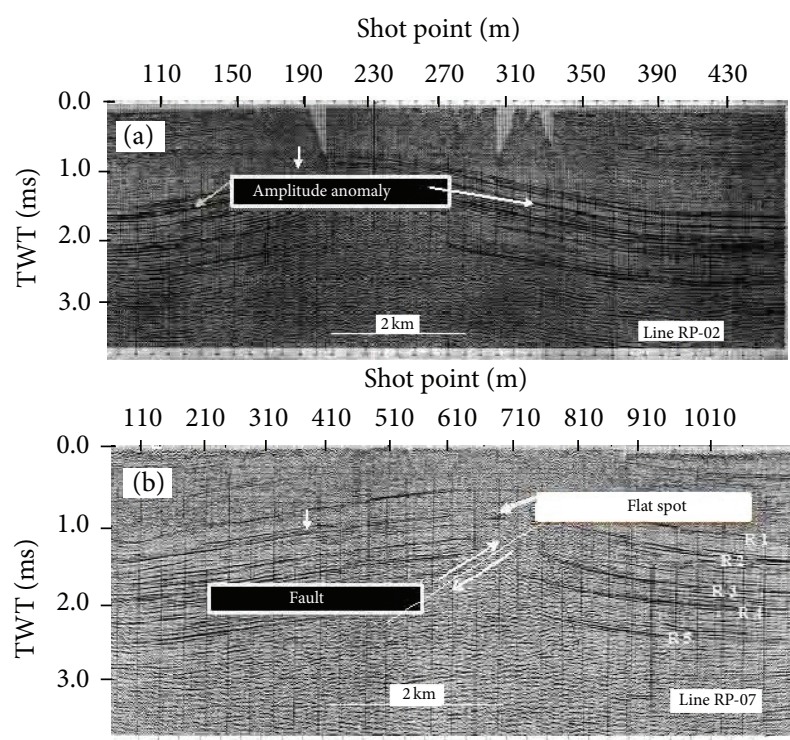

FIGURE 11: (a) Representation of amplitude anomaly along seismic line RP-02 of the Rashidpur structure. (b) shows presence of fault and flat spot along seismic line RP-07 of the Rashidpur structure.

and density contrast of the subsurface materials. The density contrast generally depends upon the degree of difference of the lithology. Such amplitude anomalies show negative RC in porous gaseous sand [25]. In the study, identified thrust fault could be compartmentalizing the gas reservoir (Table 2). The result supports the finding of Habib and Islam [26] who carried out electrofacies and core sample data analysis in the well RP \#4 of the Rashidpur structure, Bengal Basin.

\section{Conclusion}

The study attempt was to evaluate the gas sand horizons of the Rashidpur structure, Surma Basin, Bangladesh. The Upper and Lower Gas Sand reflector (R3 and R5) were identified in the top of Boka Bil and the Bhuban Formations of Early to Middle Miocene age in the Rashidpur structure. Both reflectors cover $45 \mathrm{~km}^{2}$ and $49 \mathrm{~km}^{2}$, respectively, in the structure. N-S trending thrust fault was identified which is almost parallel to the strike line having magnitude of displacement ranges from $390 \mathrm{~m}$ to $600 \mathrm{~m}$ at the middle part of the structure. The width of the fault zone is larger at the central part of the structure that becomes narrower in both directions. The velocity gradually increases with depth except for two gas sand horizons where velocity suddenly dropped. The reflection coefficients are positive at the base and negative at the top of the both gas sand horizons. High amplitude anomaly and bright spots were identified on the top of the both gas sand horizons signify as an indicator of hydrocarbon prospect. Structural maps show that the asymmetrical anticline fold and thrust fault were formed possibly due to compression, which can be correlated with the different phases of the Himalayan Orogeny. Reflections anomaly, velocity changes, and reflection coefficients suggest that two gas sand horizons existed in both side of fault of the structure.
The result reveals that the structure is potential for hydrocarbon prospect. The study recommend that if $3 \mathrm{D}$ seismic study will be conducted in the structure in order to get more clear picture of the subsurface geometry and to delineate microlevel fault of the structure.

\section{Conflict of Interests}

The authors declare that there is no conflict of interests regarding the publication of the paper.

\section{Acknowledgments}

The authors would like to acknowledge the Chairman of Bangladesh Oil, Gas and Mineral Corporation (Petrobangla) and the Managing Director of BAPEX for their kind permission to access seismic data while conducting this research work. The authors are highly grateful to Professor Dr. SultanUl-Islam, Department of Geology and Mining, University of Rajshahi, Bangladesh, for his kind supervision and proper guidance for preparing the paper. The authors thank the anonymous reviewer for improving the quality of the paper.

\section{References}

[1] M. E. Badley, Practical Seismic Interpretation, D. Reidel Publishing Company, Dordrecht, The Netherlands, 1985.

[2] M. I. Bakhtine, "Major tectonic features in Pakistan, part II: Eastern Province," Science and Industry, vol. 4, no. 2, pp. 89-100, 1966.

[3] BAPEX, "Sedimentology petrography," in Geochemistry and Biostratigraphy of Rashidpur Structure, BAPEX, Surma Basin, Bangladesh, 1989.

[4] BOGMC, "Rashidpur well no. 3 and 4," Well Completion Report, BOGMC, Dhaka, Bangladesh, 1989.

[5] I. Cohen and R. R. Coifman, "Local discontinuity measures for 3-D seismic data," Geophysics, vol. 67, no. 6, pp. 1933-1945, 2002.

[6] F. Deeba, D. Hossain, and A. Q. M. R. Rahman, “Geology and hydrocarbon potentiality of BeaniBazar structure in Surma basin Bangladesh using geophysical and well data," Bangladesh Geosciences Journal, vol. 7, 2001.

[7] F. Deeba and D. Hossain, "Subsurface mapping of the Beani Bazar anticlinal structure of Surma Basin, Bangladesh," Journal of the Geological Society of India, vol. 67, no. 2, pp. 201-210, 2006.

[8] M. B. Dobrin and C. H. Savit, Introduction to Geophysical prospecting, McGraw-Hill, Singapore, 4th edition, 1988.

[9] D. K. Guha, "Tectonic framework and oil and gas prospects of Bangladesh," in Proceedings of the 4th Annual Conference Issue, pp. 65-74, Bangladesh Geological Society, Dhaka, Bangladesh, 1978.

[10] J. G. Hagedron, "A process of seismic reflection interpretation," Geophysical Prospecting, vol. 2, pp. 85-127, 1954.

[11] K. Hiller and M. Elahi, "Structural development and hydrocarbon entrapment in the Surma Basin, Bangladesh (Northwest Indo-Burman Fold Belt)," in Proceedings of the 5th Offshore South East Asia Conference, pp. 650-663, February 1984.

[12] A. Hossain, "Evaluation of upper gas sand (UGS) in Habiganj area and the seismic response from its base indicating an alternate interpretation of gas water contact (GWC)," Bangladesh Journal of Geology, vol. 11, pp. 41-56, 1992. 
[13] D. Hossain, "On the application of common-depth-point shooting in the Surma basin, Bangladesh: a case study of the Rashidpur structure," Journal of the Geological Society of India, vol. 55, no. 2, pp. 149-156, 2000.

[14] A. Sohel, S. Kabir, and D. Hossain, "Geophysical interpretation of the rashidpur structure, surma basin, Bangladesh," Journal of the Geological Society of India, vol. 74, no. 1, pp. 39-48, 2009.

[15] A. R. M. T. Islam, M. A. Habib, M. T. Islam, and M. R. Mita, "Interpretation of wireline log data for reservoir characterization of the Rashidpur Gas Field, Surma Basin, Bangladesh," IOSR Journal of Applied Geology and Geophysics, vol. 1, no. 4, pp. 47-54, 2013.

[16] K. A. Islam and D. Hossain, "Interpretation of seismic data of the Kailas Tila Structure in the Surma Basin, Bangladesh," Journal of the Geological Society of India, vol. 60, no. 3, pp. 271-281, 2002.

[17] S. Y. Johnson and A. M. N. Alam, "Sedimentation and tectonics of the Sylhet trough, Bangladesh," Bulletin of the Geological Society of America, vol. 103, no. 11, pp. 1513-1522, 1991.

[18] M. A. M. Khan and M. Hussain, "Geology of Bangladesh gas fields," in Proceedings of the Offshore South East Asia Conference Issue, SEAPEX Session, February 1980.

[19] M. A. M. Khan, M. Islam, and M. Ahmed, "Geology and hydrocarbon prospects of the Surma Basin, Bangladesh," in Proceedings of the 7th Offshore South East Asia Conference, pp. 364367, Sita Pahar, Bangladesh, 1988.

[20] J. Leitz and J. Kabir, "New aspects on the oil and gas potential of the Bengal Basin, Bangladesh," in Proceedings of the Offshore South Asia Conference, p. 3, Singapore, 1982.

[21] M. C. Quillin, M. Bacon, and W. Barclay, An Introduction to Seismic Interpretation, Gulf Publishing Company, Houston, Tex, USA, 1979.

[22] K. U. Reimann, Geology of Bangladesh, Gerbuder Borntraeger, Berlin, Germany, 1993.

[23] A. H. M. Shamsuddin and S. K. M. Abdullah, "Geological evolution of the Bengal Basin and its implication in hydrocarbon exploration in Bangladesh," Indian Journal of Geology, vol. 69, no. 2, pp. 93-121, 1997.

[24] R. E. Sheriff, "Basic petrophysics and geophysics," in Reservoir Geophysics no. 7, Society of Exploration Geophysics, Tulsa, Okla, USA, 1992.

[25] R. E. Sheriff and L. P. Geldart, Exploration Seismology, Cambridge University Press, Cambridge, UK, 1995.

[26] A. Habib and A. R. M. T. Islam, "Paleoenvironmental reconstruction of miocene surma succession in the well rashidpur \# 04 of Bengal Basin using log facies interpretation," Iranian Journal of Earth Sciences, vol. 6, no. 1, pp. 12-23, 2014. 

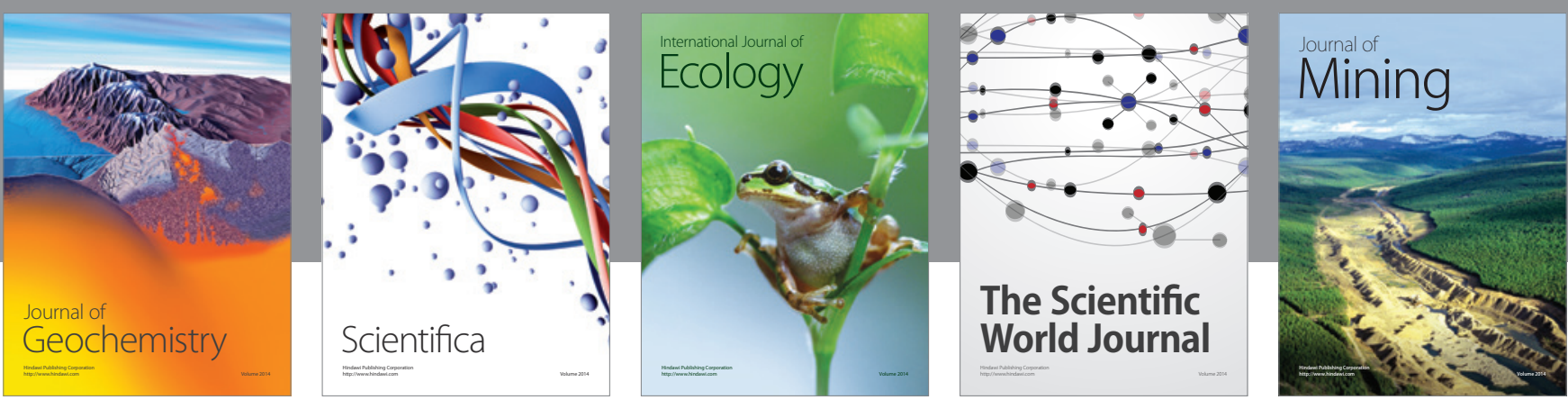

The Scientific World Journal
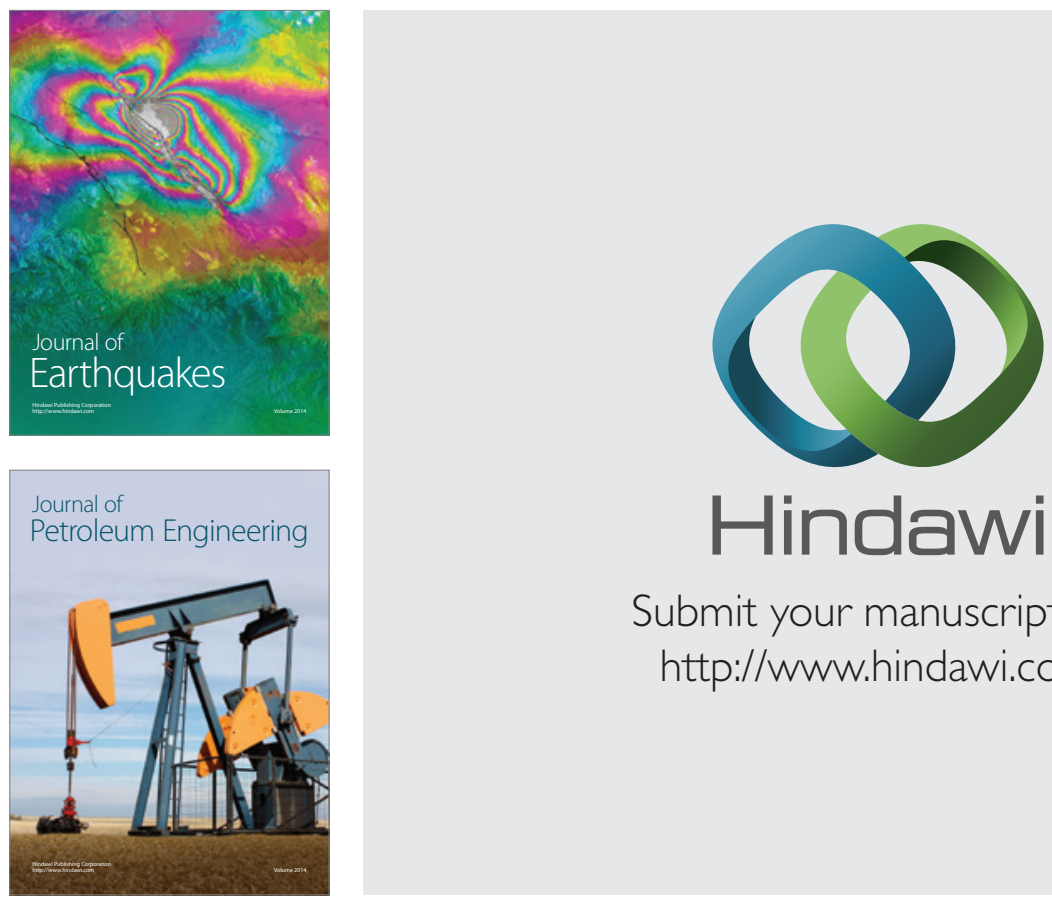

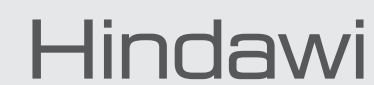

Submit your manuscripts at

http://www.hindawi.com
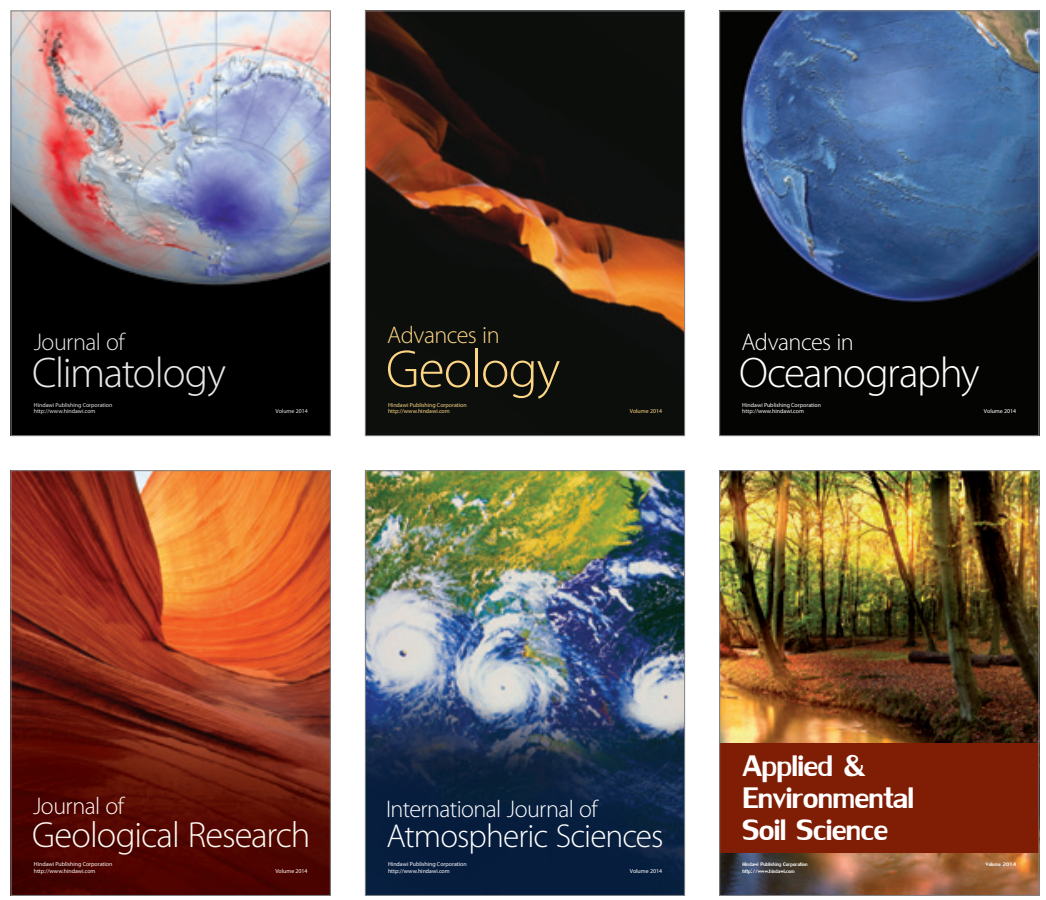
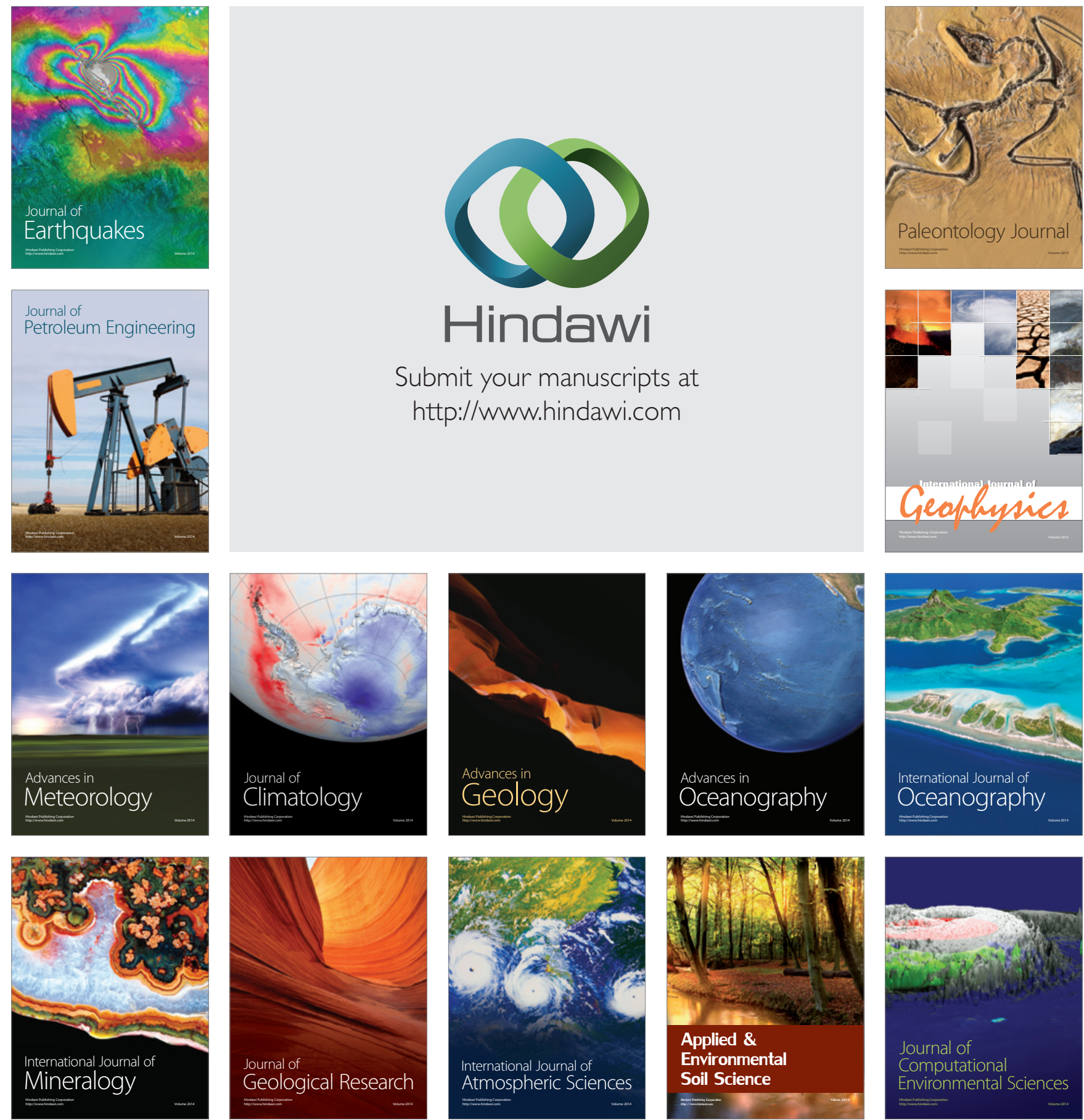